\title{
STUDI VARIASI KADAR AIR TERHADAP SIFAT FISIK DAN MEKANIK LERAK (SAPINDUS RARAK)
}

\author{
Study Of Physical And Mechanical Properties Of Lerak (Sapindus Rarak) On Different \\ Moisture Content
}

\author{
La Choviya Hawa* , Sandra Malin Sutan , I'anna Turofiq \\ Jurusan Keteknikan Pertanian - Fakultas Teknologi Pertanian - Universitas Brawijaya \\ Jl. Veteran - Malang 65145 \\ *Penulis Korespondensi, email : la_choviya@ub.ac.id
}

Disubmit: 25 Februari 2020 Direvisi: 17 Maret 2020 Diterima: 18 Maret 2020

\begin{abstract}
ABSTRAK
Perancangan alat untuk penanganan, pengeringan, pengolahan dan penyimpanan biji-bijian sangat memerlukan data sifat fisik dan mekanik. Penentuan sifat fisik dan mekanik lerak dilakukan pada rentang kadar air 11,36-26,27\%. Panjang, lebar, dan tebal rata-rata pada kondisi kadar air 11,36\% adalah 23,85 mm, 21,77 mm, dan 20,86 mm berturut-turut. Pada rentang kadar air 11,36-26.27\%, hasil penelitian pada parameter ketiga dimensi aksial, diameter rata-rata menunjukkan peningkatan secara linear, luas permukaan dari 1578,17-1846,47 $\mathrm{mm}^{2}$, kebulatan mengalami penurunan dari 0,93 menjadi 0,92 . Bulk density mengalami penurunan dari $0,69 \mathrm{gr} / \mathrm{cm}^{3}$ menjadi $0,61 \mathrm{gr} / \mathrm{cm}^{3}$ dan true density menunjukkan peningkatan dengan perubahan kadar air biji yaitu $0,82-1,00 \mathrm{gr} / \mathrm{cm}^{3}$. Porositas meningkat dari $14,65-36,68 \%$ dengan peningkatan kadar air pada rentang 11,36-26,27\%. Nilai coeficient of static friction menunjukkan peningkatan dengan peningkatan kadar air dan secara berturut-turut rentang nilai dari yang terbesar hingga yang terkecil adalah stainless steal, papan triplek, kardus, plat besi dan kaca. Pemberian uji tekan lerak pada tingkat kadar air yang berbeda menunjukkan nilai tekan yang mengalami peningkatan pada panjang adalah $63,71 \mathrm{~N}$ hingga $97,12 \mathrm{~N}$, sedangkan lebar dan tebal menunjukkan penurunan yaitu $154,19 \mathrm{~N}$ menjadi $67,67 \mathrm{~N}$ dan 130,30 N menjadi 71,88 N.
\end{abstract}

Kata Kunci : Kadar Air; Lerak (Sapindus rarak); Sifat Fisik; Sifat Mekanik

\begin{abstract}
The design of tools for handling, drying, processing and storing grains requires data on physical and mechanical properties. Determination of physical and mechanical properties of lerak carried out in the range of water content $11.365-26.271 \%$. The average length, width, and thickness in the condition of $11.365 \%$ water content were $23.85 \mathrm{~mm}, 21.77 \mathrm{~mm}$, and $20.86 \mathrm{~mm}$ respectively. In the range of water content of 11.36 $-26,27 \%$, the results of research on the parameters of the three axial dimensions, the average diameter showed an increase in linear, surface area from 1578.17-1846.47 $\mathrm{mm}^{2}$, roundness decreased from 0.93 to 0.92. Bulk density decreased from $0.69 \mathrm{gr} / \mathrm{cm}^{3}$ to $0.61 \mathrm{gr} / \mathrm{cm}^{3}$ and true density showed an increase with changes in seed moisture content from $0.82 \mathrm{gr} / \mathrm{cm}^{3}$ to $1.00 \mathrm{gr} / \mathrm{cm}^{3}$. Porosity increased from $14.65 \%-36.68 \%$ with an increase in water content in the range of $11.36-26.27 \%$. The coefficient value of static friction os shows an increase with an increase in water content and successively ranges of values from the largest to the smallest are stainless steals, plywood boards, cardboard boxes, iron plates, and glass. The application of the compressive test of lerak at different levels of water content showed that the compressive value that increased in length was 63.71-97.12 N, while width and thickness showed a decrease of 154.19 to $67.67 \mathrm{~N}$ and 130.03 $\mathrm{N}$ to $71.88 \mathrm{~N}$.
\end{abstract}

Keywords : Moisture Content; Lerak (Sapindus rarak); Physical Properties Mechanical Properties 


\section{PENDAHULUAN}

Tanaman lerak (Sapindus rarak) merupakan salah satu bentuk kearifan tradisional yang cukup dikenal oleh masyarakat dalam penggunaannya sebagai sabun tradisional. Akan tetapi seiring de-ngan perkembangan zaman, penggunaan lerak sudah mulai ditinggalkan untuk beralih pada produk sabun yang lebih prak-tis. Tanaman lerak yang termasuk dalam famili Sapindaceae dapat tumbuh dengan baik pada ketinggian 450 hingga $1.500 \mathrm{mdpl}$. Pada berbagai daerah tanaman ini mempunyai sebutan yang bervariasi, di Jawa Timur dan Tengah disebut Lerak, di Palem-bang Lamuran dan di Jawa Barat disebut dengan Rerak. Saat ini penggunakan lerak sebagai sabun banyak digunakan oleh indus-tri atau pengrajin kain batik. Kain batik yang sudah jadi dicuci dengan menggunakan lerak untuk mempertahankan warna batik.

Lerak mengandung senyawa saponin, sehingga dapat dimanfaatkan sebagai deterjen, sabun cuci piring, kosmetik, pen-cuci pakaian, shampo, biopeptisida, emas dan perak. Manfaat buah lerak dalam bidang industri yaitu digunakan untuk mencuci batik agar warnanya dapat bertahan lama dan tidak luntur (Ulung, 2014). Selain itu buah lerak juga dapat dimanfaatkan sebagai insektisida dan nematisida serta sebagai antiseptik yang sering digunakan untuk mengobati kudis (Udarno dan Balittri, 2009).

Buah lerak yang dapat dipanen yaitu buah dengan ditandai warna hijau tua hingga cokelat. Setelah dipanen buah lerak dikeringkan hingga buah menjadi kering dan berkerut. Penggunaan kembali bahan tradisional seperti lerak untuk membersihkan kain batik penting dilakukan, hal ini dikarenakan lerak merupakan bahan yang ramah lingkungan dan tidak mengandung bahan kimia yang menyebabkan pencemaran lingkungan. Dengan meningkatnya produk batik di setiap daerah, buah lerak dapat dikembangkan secara maksimal untuk memenuhi permintaan produsen batik terhadap lerak cair sebagai pencuci kain batik.

Pengetahuan tentang karakteristik fisik dan mekanik penting untuk kebutuhan data rekayasa yang diperlukan untuk perancangan mesin, proses, struktur dan pengendaliannya. Data tentang sifat fisik bahan penting dalam proses perancangan suatu peralatan seperti proses penanganan, pemisahan, pengeringan, penyimpanan dan pengolahan bahan menjadi produk seperti minuman instan (Ansar et al., 2018) . Informasi mengenai data panjang, lebar, tebal, bentuk dan diameter penting dalam proses desain alat sortasi atau pemisah. Bulk density, true density, dan porositas berkaitan dengan proses perhitungan beban struktur dan analisis ruang kerjanya (Mukhlis et al., 2017). Oleh karena itu penentuan sifat fisik dan mekanik penting dilakukan untuk meningkatkan efisiensi kerja dalam penanganan komoditi tersebut.

Pengukuran sifat fisik dan mekanik pada biji dan rempah pernah dilakukan oleh Mukhlis et al. (2017) pada lada putih, kemiri (Sinaga et al., 2016), jagung putih (Ghodsvali, 2014), jinten (Zahedi et al., 2010), biji kakao (Andasuryani et al., 2015), biji aprikot (Fathollahzadeh et al., 2008) dan biji kacang (Lawal et al., 2014), namun belum ada penelitian detail mengenai sifat fisik dan mekanik dari lerak. Oleh karena itu penting untuk dilakukan penelitian tentang sifat fisik dan mekanik lerak pada berbagai variasi kadar air.

\section{METODE}

Peralatan yang digunakan dala penelitian ini adalah Brasilliant test Soiltest Chicago tipe U-160, digital caliper dengan ketelitian $\pm 0,01 \mathrm{~mm}$, oven Memmert U30, timbangan analitik OWH tipe DJ1002A, beaker glass, lemari pendingin tipe Electrolux, sealer dan alat pengukuran angle of friction beserta permukaan geseknya.

Buah lerak didapatkan dari kabupaten Bantul Jawa Tengah dan dibeli secara online. Toluena yang digunakan sebagai pelarut dalam pengukuran true density. Air yang digunakan sebagai bahan untuk pengkondisian kadar air.

Buah lerak yang didapatkan dari kabupaten Bantul provinsi Jawa Tengah digunakan untuk semua percobaan dalam penelitian ini. Buah lerak dipisahkan secara manual dari kotoran atau benda asing yang menempel pada permukaan kulit lerak. Pada penelitian ini buah lerak yang digunakan sebanyak 1050 buah yang kemudian dibagi menjadi lima bagian sama rata untuk masing-masing kondisi kadar air dan tiga kali pengulangan. Penentuan kadar air awal 
lerak dilakukan dengan metode gravimetri atau pengeringan oven pada suhu $105 \pm 1^{\circ} \mathrm{C}$ selama 24 jam.

Variasi kadar air pada sampel lerak dapat ditentukan dengan menggunakan metode penambahan massa destilasi air dengan mengikuti persamaan (1) (Isik dan Izli, 2016).

$Q=\frac{W i(M f-M i)}{(100-M f)}$

Dimana $Q$ adalah massa air yang ditambahkan (kg); $M_{i}$, kadar air awal sampel (\% bb); $M_{f}$, kadar air akhir sampel (\% bb) dan $W_{i}$ adalah massa awal sampel $(\mathrm{kg})$. Kemudian sampel yang sudah ditambahkan air sesuai dengan perhitungan dimasukkan kedalam plastik polietilen dan ditutup rapat dengan menggunakan sealer. Untuk memastikan kadar air terdistribusi secara merata, sampel yang sudah ditutup rapat di masukkan dalam refrigerator pada suhu sebesar $5^{\circ} \mathrm{C}$. Sebelum dilakukan pengujian sampel yang dibutuhkan dikeluarkan dari refrigerator dan didiamkan pada suhu ruang selama 2 jam (Isik dan Izli, 2016). Semua sifat fisik dan sifat mekanik dinilai pada tingkat kadar air $11,36 \%, 14,68 \%, 18,18 \%, 22,87 \%$ dan $26,27 \%$ dengan tiga kali pengulangan pada masing-masing variasi kadar air.

Untuk menentukan dimensi rata-rata buah lerak 150 buah lerak diambil secara acak dan dilakukan pengukuran dimensi aksial yaitu panjang, lebar dan tebal menggunakan jangka sorong dengan ketelitian $0,01 \mathrm{~mm}$. Ketiga dimensi aksial ditentukan $\mathrm{L}$ = sumbu terpanjang, $\mathrm{W}=$ sumbu terpanjang yang tegak lurus dengan $\mathrm{L}$ dan $\mathrm{T}=$ sumbu terpanjang yang tegak lurus dengan $\mathrm{L}$ dan $\mathrm{W}$. Diameter rata-rata buah lerak dihitung dengan menggunakan rata-rata aritmatik $(\mathrm{Da})$, geometrik (Dg), kuadrat (Dk) dan Ekuivalen (DE). Keempat diameter rata-rata tersebut dihitung dengan menggunakan persamaan 2,3,4 dan 5 (Andasuryani et al,2015).

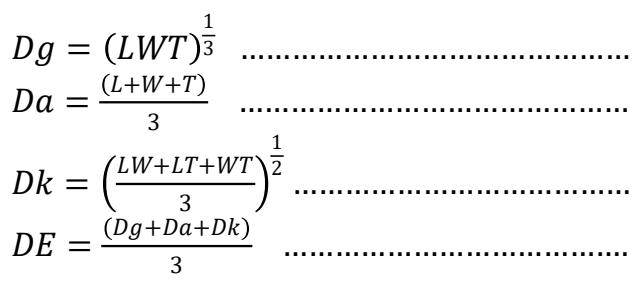

Luas permukaan (S) buah lerak dapat dihitung menggunakan persamaann 6 (Khodaei dan Akhijahani, 2012; Fathollahzadeh et al., 2008).

$S=\pi D g^{2}$

Sphericity (Kebulatan) dihitung menggunakan persamaan 7 (Sinaga et al., 2016).

$\Phi=\frac{(L W T)^{\frac{1}{3}}}{L}$

Penentuan parameter bulk density dilakukan dengan cara mengisi wadah kosong bervolume $1000 \mathrm{ml}$ dengan sampel lerak. Cara pengisiannya yaitu pada ketinggian yang sama dengan kecepatan konstan. Kemudian wadah beserta isinya ditimbang dan dihitung nilai bulk density dari massa sampel dan volume wadah (Mollazade et al, 2009).

True density didefinisikan sebagai rasio antara bobot biji dan volume biji yang sebenarnya, penentuan true density dilakukan dengan menggunakan metode perpindahan toluena. Metode tersebut digunakan karena penyerapan oleh biji terjadi pada tingkat yang lebih rendah. Berat toluena yang dipindahkan didapatkan dari sampel yang sudah diketahui massanya dicelupkan kedalam wadah berisi toluena. Menurut Moghadam et al. (2015) penelitian sebelumnya pada sampel kurma untuk menghitung true density dapat menggunkan persamaan sebagai berikut:

$\rho t=\frac{M a}{V t}$

Porositas dapat diartikan sebagai perbandingan antara volume total pori-pori bahan dengan volume wadah yang dinyatakan dalam satuan persen. Beberapa penelitian sebelumnya yang telah dilakukan Sangamithra et al. (2016) pada biji jagung, Mollzade et al. (2009) pada jinten dan Andasuryani et al. (2015) pada biji kakao nilai porositas dapat dihitung dengan menggunakan persamaan sebagai berikut:

$\% \varepsilon=\left(1-\frac{\rho b}{\rho t}\right) \times 100 \%$ 
Angle of static friction didefinisikan sebagai sudut yang terbentuk oleh biji atau sampel saat mulai meluncur pada permukaan gesekan. Permukaan gesekan yang pada umumnya digunakan adalah stainless steal, plat besi, dan papan triplek. Penggunaan permukaan gesek tersebut didasarkan pada material untuk penyimpanan, penanganan dan transportasi (Andasuryani et al, 2015). Menurut Sangamithra et al (2016) penelitian pada biji jagung nilai angle of friction dihitung dengan menggunakan persamaan berikut:

$\mu=\tan \alpha$

Sifat mekanik merupakan respon material (bahan) terhadap pembenanan yang diberikan seperti gaya, torsi, atau gabungan keduanya. Tujuan dilakukannya uji tekan pada bahan adalah untuk mendapatkan data sifat mekanik dari bahan. Pengujian mekanik biasanya bersifat merusak (destructive test). Menurut Sinaga et al. (2016) uji tekan dilakukan dengan menggunakan universal testing machine (UTM) untuk mengetahui beban maksimal pada bahan uji.

\section{HASIL DAN PEMBAHASAN}

\section{Dimensi dan Diameter rata-rata}

Dimensi rata-rata aksial lerak berupa panjang, lebar dan tebal secara berturutturut pada tingkat kadar air 11,36-26,27\% adalah 24,15-26,23 mm, 22,03-23,41 $\mathrm{mm}$ dan 21,13-23,17 mm. Grafik hubungan kadar air dengan dimensi aksial lerak dapat dilihat pada Gambar 1.

Diameter rata-rata (geometrik, aritmetik, kuadrat, ekuivalen) buah lerak dihitung pada rentang variasi kadar air 11,36-26,27\%. Hasil diameter rata-rata geometrik buah lerak adalah sebesar 22,39-24,22 mm dengan mengalami kenaikan sebesar 0,09-3,56\%. Nilai diameter rata-rata aritmetik pada buah lerak sebesar 22,44-24,27 mm dengan presentase kenaikan sebesar $0,1-3,6 \%$. Hasil perhitungan diameter rata-rata kuadrat didapatkan nilai rata-rata sebesar 22,41-24,24mm dengan presentase kenai-kan sebesar 0,1$3,6 \%$. Sedangkan untuk nilai rata-rata diameter rata-rata ekuivalen adalah sebesar 22,41$24,25 \mathrm{~mm}$ dan presentase kenaikan sebesar $0,1-3,37 \%$. Penentuan nilai diameter rata-rata dipengaruhi oleh nilai pada masing-masing dimensi, apabila setiap kenaikan kadar air berpengaruh pada nilai dimensi maka akan berpengaruh juga pada setiap nilai diameter rata-ratanya. Grafik hubungan kadar air dengan diameter rata-rata lerak dapat dilihat pada Gambar 2.

Berdasarkan nilai yang dihasilkan dapat dilihat bahwa apabila nilai kadar air pada bahan tinggi maka nilai dimensi diameter rata-rata juga akan semakin besar. hal tersebut dikarenakan sejumlah massa air masuk kedalam buah lerak dan menempati sel sel didalam buah lerak tersebut. Sehingga daging buah lerak akan mengembang. Hasil tersebut tidak jauh berbeda antara buah anggur dan buah lerak, dikarenakan bentuk buah yang hampir sama pula. Hasil serupa dari peningkatan dimensi aksial juga terjadi pada penelitian Moghadam et al. (2015) dengan bahan buah kurma dan Sangamithra et al. (2016) dan Bhise et al. (2014) pada biji jagung.

\section{Massa dan Peel ratio}

Massa buah lerak meningkat secara linier dari 5,25-6,61 gram dengan nilai minimum sebesar 2,68 gram dan nilai maksimum sebesar 10,12 gram. Standar deviasi dari data massa lerak berada pada kisaran 0,94-1,07. Dengan demikian terjadi peningkatan massa buah lerak sebesar 9,86-12,66\% pada rentang kadar air tersebut. Proses penambahan sejumlah massa air untuk meningkatkan kadar air lerak menyebabkan massa lerak juga meningkat. Hal ini dikarenakan terjadi penambahan se-jumlah massa air kedalam bagian daging buah lerak pada saat proses pengondisian kadar air. Sehingga pada rentang kadar air 11,36-26,27\% massa lerak mengalami peningkatan. Grafik hubungan kadar air dengan massa lerak dapat dilihat pada Gambar 3.

Nilai rata-rata peel ratio pada rentang kadar air 11,36-26,27\% sebesar 41,90-55,37\%. Pada Gambar 4. dapat dilihat apabila nilai kadar air tinggi maka peel ratio juga memiliki nilai yang besar, hal ini dikarenakan semakin tinggi kadar air maka kemungkinan besar sejumlah massa air akan diserap oleh bahan dan menempati pori-pori pada daging buah lerak, sehingga menyebabkan massa lerak bertambah dan peel ratio akan semakin besar.

Massa dan peel rasio lerak mengalami peningkatan secara linier seiring dengan me- 
ningkatnya kadar air, hal tersebut sama halnya dengan yang telah dituliskan Moghadam et al. (2015) dengan penelitian sifat fisik dan mekanik pada komoditi biji kurma dan Razavi and Parvar (2007) dengan sampel berupa buah kiwi.

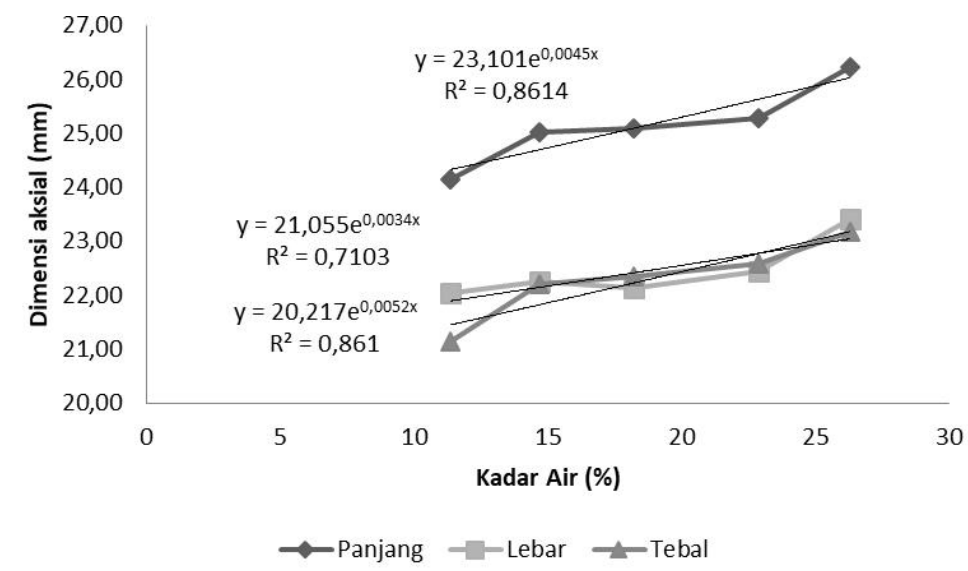

Gambar 1. Hubungan kadar air dengan dimensi aksial lerak

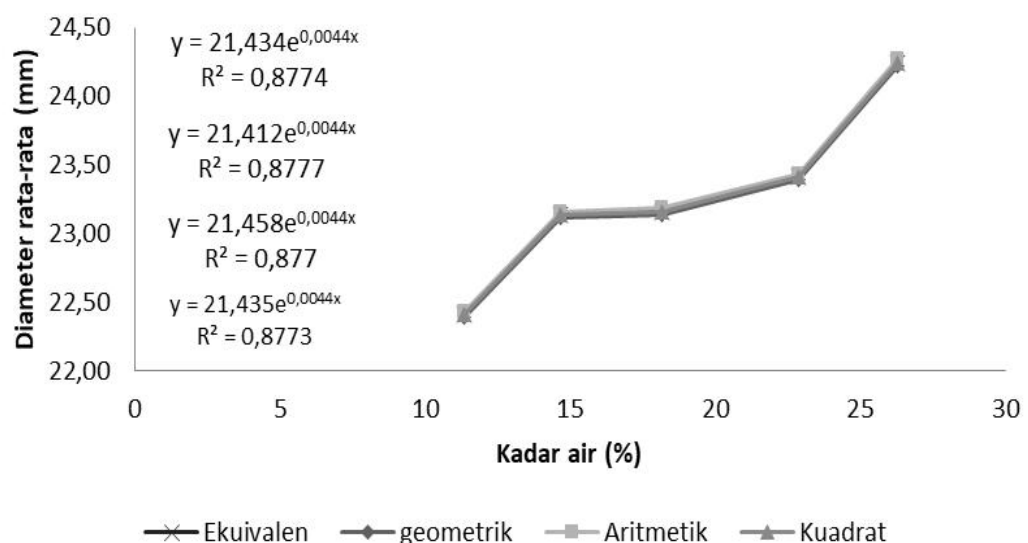

Gambar 2. Hubungan kadar air dengan diameter rata-rata lerak

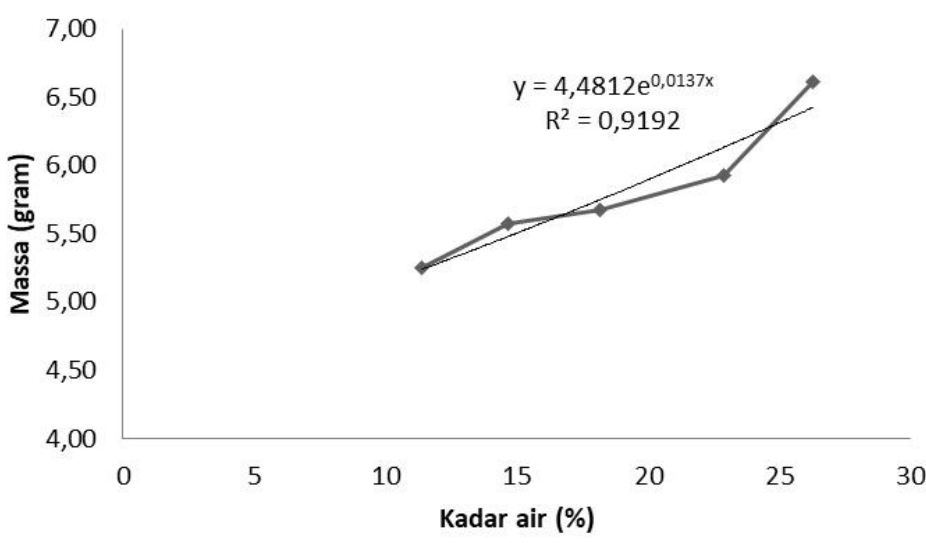

Gambar 3. Hubungan kadar air dengan massa lerak 


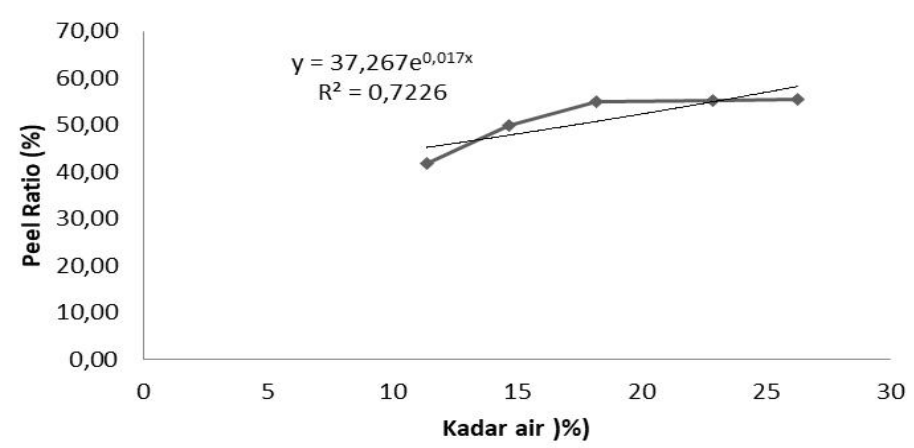

Gambar 4. Hubungan kadar air dengan peel ratio lerak

\section{Sphericity (Kebulatan)}

Pada rentang kadar air 11,36-26,27\% nilai sphericity buah lerak mulai dari $0,92-$ 0,93 , nilai standar deviasi sebesar 0,02 hingga 0,03 , nilai minimum sebesar 0,838 dan nilai maksimum sebesar 0,997. Dengan demikian terjadi penurunan sphericity sebe-sar 0,05$0,36 \%$. Grafik hubungan kadar air dengan sphericity lerak dapat dilihat pada Gambar 5.

Hal tersebut sudah sesuai dengan penelitian sebelumnya yakni menurut Moghadam et al. (2015) pada biji kurma yang menyatakan bahwa nilai kebulatan biji kurma menurun dari 0,5 menjadi 0,8 dengan peningkatan kadar air di kisaran $7-30 \%$. Kecenderungan penurunan nilai sphericity dengan peningkatan kadar air juga terjadi pada biji kakao dengan nilai kebulatan berkisar 0,47-0,67 dengan nilai rata-rata 0,56. Dapat dilihat bahwa nilai sphericity meningkat dengan menurunya ukuran biji (Andasuryani et al., 2015).

\section{Surface Area (Luas permukaan)}

Nilai rata-rata surface area pada rentang kadar air 11,36-26,27\% adalah sebesar $1578,17-1846,47 \mathrm{~mm}^{2}$. Nilai minimum dan maksimum surface area buah lerak adalah sebesar 1090,44 $\mathrm{mm}^{2}$ dan 2265,68 $\mathrm{mm}^{2}$ dengan nilai standar deviasinya sebesar 161,00-218,22. Peningkatan kadar air diikuti dengan peningkatan nilai surface area pada buah lerak dengan nilai peningkatan sebesar $1,5-7,05 \%$. Nilai surface area sangat dipengaruhi oleh ketiga dimensi buah lerak seperti panjang, lebar dan tebal. Sehingga apabila dimensi aksial buah lerak meningkat seiring dengan peningkatan kadar air, maka nilai surface area juga mengalami pening-katan. Grafik hubungan kadar air dengan surface area lerak dapat dilihat pada Gambar 6 .
Hasil perhitungan surface area pada buah lerak sesuai dengan penelitian sebelumnya menurut Isik dan Izli (2015) pada bahan lentil dan Mukhlis et al. (2017) pada bahan biji lada putih.

\section{Bulk density dan True density}

Nilai rata-rata bulk density pada rentang kadar air 11,36-26,27\% adalah sebesar 0,608 $0,688 \mathrm{~g} / \mathrm{cm}^{3}$. bahwa nilai bulk density mengalami penurunan sebesar 0,1-9,5\% dengan meningkatnya kadar air bahan. Hal tersebut terjadi karena dengan mening-katnya kadar air volume dari buah lerak juga meningkat sehingga dengan kapasitas wa-dah yang tetap buah lerak yang dapat menempati wadah semakin berkurang.

Pada penelitian ini antara kadar air dengan bulk density menyatakan hubungan linier negatif seperti pada sampel lentil kuning menurut Isik dan Izli (2015) dan Gharibzahedi et al. (2011) pada biji jarak. Grafik hubungan kadar air dengan bulk density dan true density lerak dapat dilihat pada Gambar 7.

Nilai rata-rata true density buah lerak pada rentang kadar air 11,36-26,27\% adalah 0,8226-1,0009 $\mathrm{g} / \mathrm{cm}^{3}$. Peningkatan true density pada penelitian ini cukup signifikan mulai dari tingkat kadar air 11,36-22,87\% dengan presentase kenaikan sebesar 0,25\%$15,92 \%$. Hasil nilai true density buah lerak pada penelitian ini, dimana nilai true density akan semakin besar seiring dengan meningkatnya kadar air. Hal tersebut dapat dikarenakan oleh bertambahnya massa pada lerak saat proses pengondisian kadar air, dan berpengaruh terhadap bertambahnya volume air pada pengukuran true density (Shreelavaniya dan Kamaraj, 2017). 


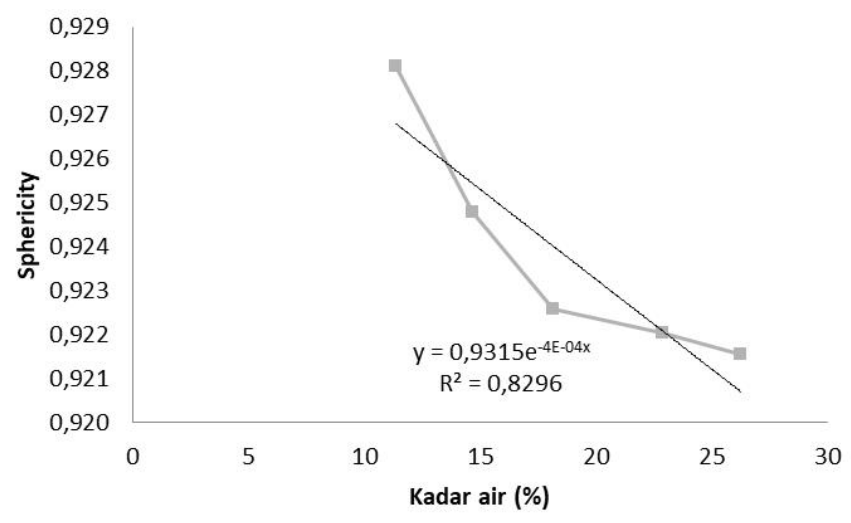

Gambar 5. Hubungan kadar air dengan sphericity lerak

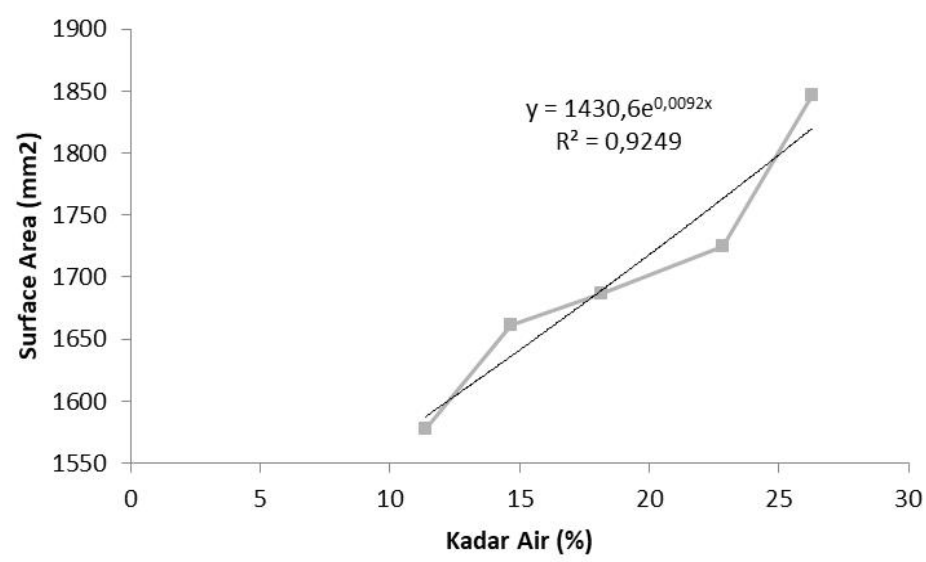

Gambar 6. Hubungan kadar air dengan surface area lerak

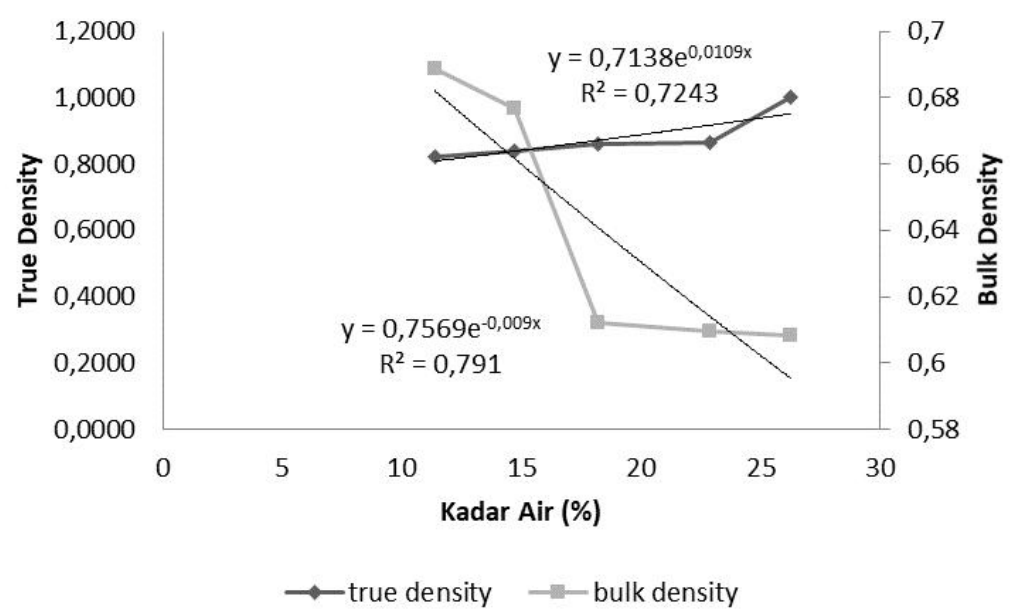

Gambar 7. Hubungan kadar air dengan bulk density dan true density lerak

\section{Porositas}

Nilai rata-rata porositas pada rentang kadar air $11,36-26,27 \%$ yaitu sebesar $14,65-$ $36,67 \%$ dengan nilai standar devi-asinya sebesar 11,31-13,72. Presentase ke-naikan porositas buah lerak adalah sebesar 8,3$47,9 \%$. Hasil perhitungan porositas de-ngan hubungan yang berbanding lurus dengan kadar air pada dasarnya dipengaruhi oleh nilai true density dan bulk density. Sesuai dengan persamaan untuk menghitung porositas, nilai porositas akan semakin tinggi apabila nilai true density lebih besar dibandingkan dengan bulk density. Pada penelitian ini hasil perhitungan porositas tidak jauh berbeda dengan pola yang dibentuk oleh persamaan linier jinten hitam (Zahedi et al., 2014). Grafik hubungan kadar 
air dengan porositas lerak dapat dilihat pada Gambar 8.

\section{Angle of Friction}

Pada rentang kadar air $11,36 \%$ sampai $26,27 \%$ nilai rata-rata coefficient of static friction pada permukaan kaca adalah sebesar 0,398-0,497 dengan presentase kenaikan sebesar $1,9-10,9 \%$. Pada permukaan gesek plat besi nilai rata-rata coefficient of static friction yaitu sebesar 0,36-0,54 dengan pre-sentase kenaikan sebesar $1,7-26,9 \%$. Nilai rata-rata coefficient of static friction pada per-mukaan kardus yaitu 0,38- 0,51 dengan presentase kenaikan sebesar 0,01-21,34\%. Pada permukaan gesek stainless nilai rata-rata coefficient of static friction yaitu $0,42-0,68$ dan nilai presentase kenaikan sebesar 4,12-26,39\%. Sedangkan pada permukaan papan triplek nilai rata-rata coefficient of friction yaitu sebesar 0,36-0,57 dan presentase kenaikan sebesar 0,1-29,26\%. Grafik hubungan kadar air dengan Ccoefficient of Static Friction lerak dapat dilihat pada Gambar 9.

Besar kecilnya nilai coeficient of static friction dapat dipengaruhi oleh tingkat kehalusan dan kekasaran permukaan gesek yang digunakan. Permukaan gesek yang kasar dapat menghambat bahan untuk meluncur lebih cepat, sehingga sudut yang terbentuk pada saat bahan mulai meluncur akan semakin besar. Hal serupa juga terjadi pada penelitian sebelumnya seperti menurut Gharibzahedi et al. (2011) pada biji jarak,
Shreelavaniya dan Kamaraj (2017) pada lada hitam, Zahedi et al. (2010) pada jinten hitam dan Seyed et al. (2007) pada biji labu.

\section{Compressive Force (Gaya Tekan)}

Pada rentang kadar air 11,36-26,27\% untuk uji gaya tekan yang tegak lurus dengan panjang memiliki nilai rata-rata gaya tekan yaitu sebesar 64,07-97,12 N, meningkat sebesar 1,55-27,89\% seiring dengan meningkatnya kadar air. Pengujian gaya tekan pada posisi tegak lurus dengan lebar memiliki rata-rata gaya tekan sebesar $67,67-154,19 \mathrm{~N}$, mengalami penurunan sebesar 4,2-29,7\%. Sedangkan pada posisi tegak lurus dengan tebal nilai rata-rata gaya tekan buah lerak yaitu sebesar 71,88-130,30 N mengalami penurunan sebesar 3,25-19,4\%.

Pada penelitian ini, buah lerak pada dasarnya tidak memiliki cangkang, hanya terdiri dari daging buah dan biji, sehingga hasil gaya tekan pada posisi tegak lurus dengan lebar dan tebal tidak linier dengan kadar air. Penurunan nilai gaya tekan dengan naiknya kadar air bahan juga dinyatakan oleh Mollazade et al. (2009) pada bahan jinten yang menyatakan bahwa gaya tekan pada biji dengan posisi tegak lurus dengan panjang dan lebar menurun dari $83,74 \mathrm{~N}$ menjadi $56,17 \mathrm{~N}$ dan 132,95 menjadi 84,47 N. Hasil tersebut berada pada rentang kadar air 7,24-21,38\% basis kering. Grafik hubungan kadar air dengan gaya tekan lerak pada gambar 10 .

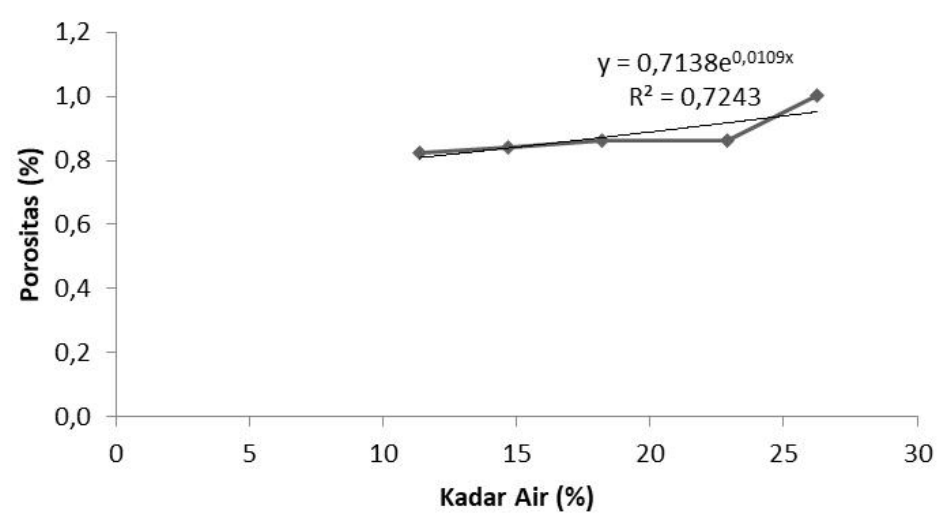

Gambar 8. Hubungan kadar air dengan porositas lerak 


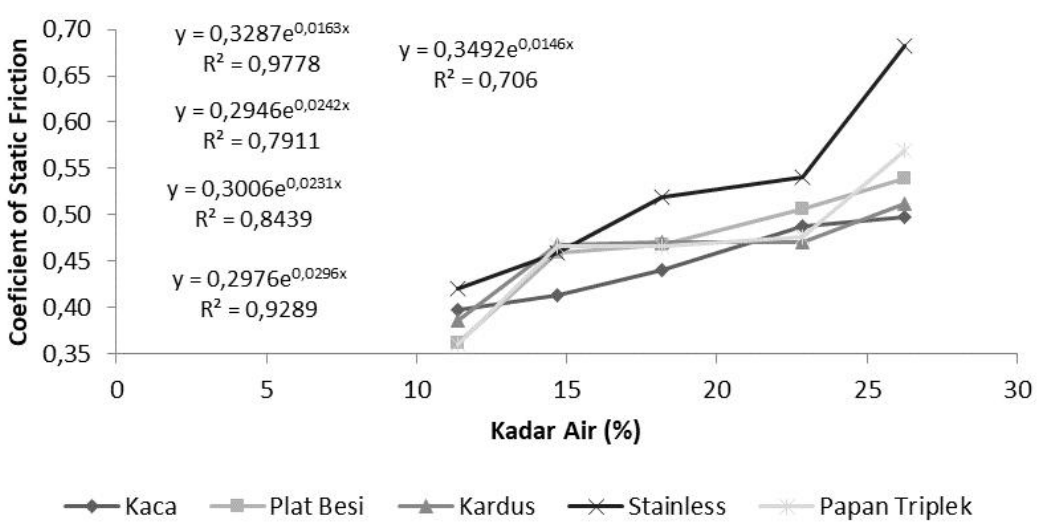

Gambar 9. Hubungan kadar air dengan coefficient of static friction lerak

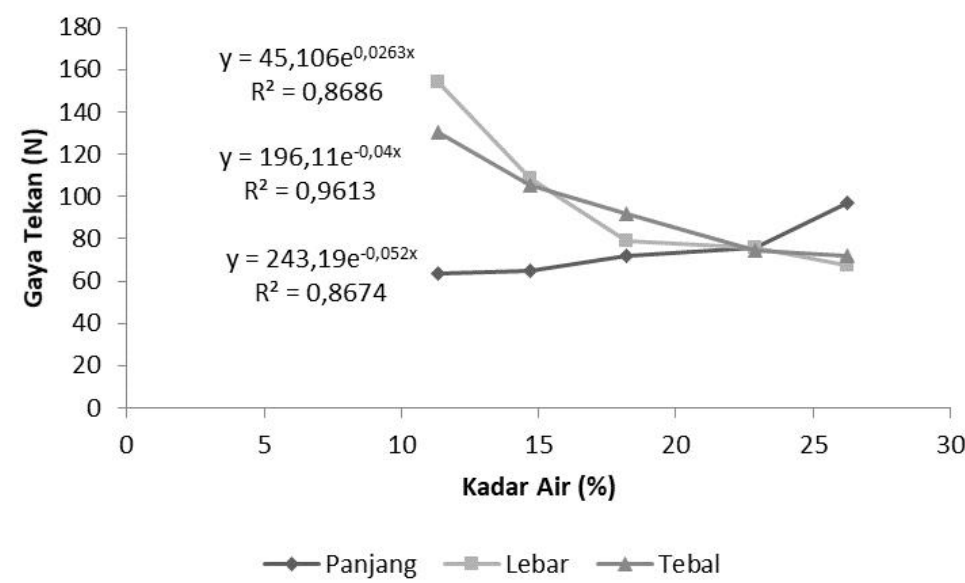

Gambar 10. Hubungan kadar air dengan gaya tekan lerak

\section{SIMPULAN}

Kesimpulan dari penelitian ini diambil berdasarkan hasil penelitian dengan sifat fisik dan sifat mekanik biji lerak pada tingkat kadar air $11,36-26,27 \%$. Sifat fisik buah lerak yang dipelajari dalam penelitian ini semuanya memiliki korelasi yang tinggi terhadap peningkatan kadar air biji. Ketiga dimensi aksial, diameter rata-rata, dan surface area pada buah lerak mengalami peningkatan dengan meningkatnya kadar air biji dari 0,09$7,05 \%$. Nilai sphericity dan Bulk density mengalami penurunan dengan meningkatnya kadar air pada biji pala dengan presentase penurunan sebesar 0,05-9,5\%. True density dan Porositas biji pala menga-lami peningkatan dari $0,25-15,92 \%$ dan $8,3-47,9 \%$ dengan peningkatan kadar air buah lerak. Untuk nilai coefficient of friction menga-lami kenaikan seiring dengan peningkatan pada kadar air biji pala. Untuk gaya tekan buah lerak pada rentang kadar air $11,365 \%$ hingga $26,27 \%$ pada posisi tegak lurus dengan panjang mengalami kenaikan se-besar 1,50-27,89\%, pada posisi tegak lurus dengan lebar dan tegak lurus dengan tebal mengalami penurunan sebesar $4,20-29,70 \%$ dan $3,25-19,41 \%$.

\section{DAFTAR PUSTAKA}

Andasuryani, -P,N, Sutan, -SM. 2015. Kajian sifat-sifat fisik buah dan biji kakao (Theobroma Cocoa L.). Jurnal Teknologi Pertanian Andalas. 19(1), 1-9. https:/ / doi. org/10.25077/jtpa.19.1.1-9.2015

Ansar, Nazaruddin, Alamsyah, -A, Aziz -AD. 2018. Analisis korelasi antara ukuran diameter dan bentuk permu-kaan partikel dengan laju aliran gra-nula stroberi. Jurnal Ilmiah Rekayasa Perta-nian dan Biosistem. 6(2), 125-130. https://doi.org/10.29303/jrpb.v6i2.85

Fathollahzadeh, -H, Mobli, -H, Beheshti, -B, Jafari, -A, Borghei, -AM. 2008. Effect of moisture content on some physical properties of apricot kernel (Cv. Sonnati Salmas). Agricultural Engineer-ing Interna- 
tional : The Cigr Ejournal 10(1), 1-14. https://cigrjournal.org/index.php/Ejou $\mathrm{nral} /$ article/view/1220

Gharibzahedi, -SMT, Mousavi, -M, Ghahderijani, -M. 2011. A survey on moisture-dependent physical proper-ties of castor seed (Ricinus Communis L.). Australian Journal Of Crop Science. 5(1), 17. http://www.cropj.com/gharibzahedi _5_1_2011_1_7.pdf

Isik, E and Izli, -N. 2016. Effects of moisture content on some physical properties of the yellow lentil. Journal Of Agricultural Sciences. 22(2016), 307-316. https://doi .org/10.1501/Tarimbil0000001389

Khodaei, -J., Akhijahani, HS.2012. Some physical properties of rasa grape (Vitis vinivera L.). World Applied Sciences Journal 18(6): 818-825. http://doi.org /10.5829/ idosi.wasj.2012.18.06.1473

Lawal, -AA, Aviara, -A, Kawuyo, -UA. 2014. Some physical and frictional properties of sweet detar nut and seed. Continental Journal of Engineering Science. 9(1), 26-35. http://doi.org/10.5707/cjengsci.2014.9.1. 26.35

Moghadam, -MS, Beygi, -SRH, Aboonajmi, -M. 2015. Moisture dependent physical and mechanical properties of mazafati date pit. Agricengint 17(2), 228-242

Mollazade, -K, Ahmadi, -H, Khorsidi, J, Rajabipour, -A, Mohtasebi, -SS. 2009. Moisture-dependent physical and mechanical properties of Cumin (Cuminum Cyminum L.) Seed. Int J Agric \& Biol Eng 2(2): 49-56 http:// doi.org/10.10.3965/j.is sn.1934-6344.2009.02.049-056

Mukhlis, -AMA, Hartulistiyoso, -E, Purwanto, -YA. 2017. Pengaruh kadar air terhadap beberapa sifat fisik biji lada putih. Agritech. 37(1), 15-21. http://doi.org/10. $.22146 /$ agritech.15308

Ramadhani, -A, Darsono, Budianto, -A, Suhartono. 2016. Penentuan sphericity dan distribusi intensitas berkas elektron dari sumber elektron tipe pierce berbasis matlab. Jurnal Forum Nuklir (Jfn) 12(2), 53-64
Razavi, -SMM., Parvar, -MB. 2007. Some Physical and Mechanical Properties of Kiwi Fruit. International Journal of Food. 3(6): 1-14. https:// doi.org/10.2202/155 6-3758.1276

Bhise, -S., Kaur, -A, Manikantan, -R. 2014. Moisture dependent physical propertirs of maize (PMH-1). Acta Alimentaria. 43 (3), 394-401. https://doi.org/10.1556/AAlim. 43.2014.3.5

Sangamithra, -A, John, -SG, Sorna, -PR, Nandini, -K, Kannan, -K, Sasikala, -S, Suganya, -P. 2016. Moisture dependent physical properties of maize kernels. International Food Research Journal 23(1), 109-115. http://www.ifrj.upm.edu.my/ 23\%20(01)\%202016/(17).pdf

Shreelavaniya, R and Kamaraj, S. 2017. Effect of moisture content on physical properties of black pepper. International Journal Of Current Microbiology And Applied Science 6(10), 4873-4879. https://doi.org/10.20546/ijcmas.2017.61 0.456

Sinaga, -R, Desrial, Wulandani, -D. 2016. Karakteristik fisik dan mekanik kemiri (Aleurites moluccana Wild.). Jurnal Keteknikan Pertanian. 4(1),97-106. https: //doi.org/10.19028/jtep.04.1.97-106

Udarno, -L., Balittri. 2009. Lerak (Sapindus rarak) tanaman industri pengganti sabun. Warta Penelitian dan Pengembangan Tanaman Industri. 15(2), 7-8. http:// perkebun an.litbang.pertanian.go.id/lerak-sapin dus-rarak-tanaman-industri-penggantisabun/

Ulung, -G. 2014. Sehat alami dengan herrbal "250 Tanaman Herbal Berkasiat Obat". PT Gramedia Pustaka Utama : Jakarta

Zahedi, -SMTG, Mousavi, -SM, Moayadi, -A, Garavand, AT, Elizadeh, SM. 2010. Moisture-Dependent Engineering Properties of Black Cumin (Nigella Sativa L.) Seed. The CIGR Ejournal. 7, 1-17. https://cigrjournal.org/index.php/Ejou nral/article/view/1437 